\title{
Organizational and Economic Fundamentals of Formation of Investment Funds Improvement
}

\author{
Sultonboeva Munira Baxodirovna, \\ Tashkent Turin Polytechnic University, \\ Associate Professor of "Socio-Economic Sciences", Dsc \\ Tel .: (+99890) -8065509 \\ Email: munira.khodieva@gmail.com
}

\begin{abstract}
The article examines the organizational and economic basis for the formation of investment funds and the theoretical and methodological basis for improving the mechanism of its implementation. Factors influencing the process of formation of investment funds have been systematically studied. Scientific proposals and practical recommendations for improving the organizational and economic framework for the formation of investment funds have been formed.

Keywords: investment fund, stock market, investment portfolio, investment assets, financial resource, stock market, tax credit, financial sector.
\end{abstract}

\section{INTRODUCTION}

The success of any reform will depend on the study of world experience, especially the practice of economically developed countries, and the appropriate application of its positive aspects to the national economy. Investment funds are named differently in most countries of the world, but the functions they perform are almost the same. Investment funds offer a reduction in the risk and cost of investing directly in securities. Investment fund managers offer shareholders the opportunity to place their funds in the fund, ie other investment funds. This solves the problem of selection and asset diversification. However, these benefits come at the expense of high commission costs and low returns. The main purpose of investment funds is to centralize the funds of the general population, ie to attract them to the investment process.

The need for the development of investment funds arises due to the accumulation of temporarily vacant funds in the population, their mobilization for profit and investment in various sectors of the national economy on the basis of mutual interests. The issue of using temporarily free funds of the population as investments was raised by the President of the Republic of Uzbekistan Sh.M. In his address to the Oliy Majlis, Mirziyoyev stated that "one of our important tasks in the development of the economy is to mobilize the funds accumulated in the hands of the population in the form of investments, to strengthen the sense of entrepreneurship." [1]

Experts and economists of the country are also studying the possibility of using investment funds to reduce the share of the "shadow economy" in the national economy using economic methods. Countries such as Russia and Kazakhstan have also advised citizens (property owners) to take advantage of capital (stock) market opportunities to ensure the transparency of their wealth 
under "capital amnesty".

As a property owner, an investor should also have information about their economic advantage in choosing investment funds to benefit from the efficient placement of their funds. Therefore, it is important for a trust manager to assess their economic benefits and, if necessary, take measures to improve them.

\section{REFERENCES}

Regarding the economic benefits of investment funds, economist U.Sharp called the "Beta Coefficient" [2], while P.Shtolte described the "magic triangle" associated with the placement of capital by the investor through the security of capital investment, its growth and dividend income [ 3]. Russian scientists A. E.Abramov, K. S.Akshentseva, M.I.Chernova, D. A. Loginova, D. V.Novikov, A. D.Radygin, Yu. The diversification of the investment portfolio by V. Sivay and the distribution of the net present value owned by investors in proportionate shares [4], in A.D. Radigin's research, consider investment funds as legal entities or property complexes managed by specialized companies, in which conducted research on the need to focus on diversification. Uzbek economist Sh.Sh.Shokhazami in his research, the direction of financial resources in the form of investments in financial instruments of issuers [6], RBSaidov, the state of securities in the financial sector of the economy [7], MASultanov's economic systematization ( methods) to study them simultaneously as participants in three levels of systemic relations and the creation of mutually beneficial mutual investment funds in commercial banks of Uzbekistan [8], as well as the use of legal-Islamic securities as a financial instrument CZ Abrorov [9].

\section{RESEARCH METHODOLOGY}

In our research method on the economic advantages of investment funds, that is, on the basis of the rules of economic systematization (methodology) to study them as participants in three levels of systemic relations, as well as the object of research is a clear criterion of investment funds as an independent system. procedures can be introduced. Scientific research methods such as system analysis, institutional analysis, functional analysis, comparative analysis, analysis and synthesis were also used in this research process.

\section{ANALYSIS AND RESULTS}

"Issuance of additional shares to ensure an average doubling of the total capital of commercial banks in 2017-2021", "Attracting deposits of the population and businesses in 2017-2021 to strengthen the resource base of commercial banks by at least 2.1 times, as well as in the future" "Creating a legal framework for the circulation, issuance and redemption of unsecured bonds and mortgage securities", as well as "allowing banks, insurance companies, large state-owned companies, joint stock companies to issue securities (bonds, promissory notes, etc.)" the need to create mutual funds in banks will increase.

In world practice, the organizational models of mutual funds as a type of collective investment institutions (in many sources, synonymously called investment funds) are studied through AngloSaxon, continental (European, German), hybrid and Islamic models. nobank are also referred to as hybrid models. Among them, the continental (European, German) model covers the characteristics of the development of mutual funds in European countries and relies mainly on banking institutions as 
financial intermediaries. In Germany, the law on investment companies (KAGG) underlies the operation of mutual funds. Because these companies play a special role in managing the assets of investment funds. According to this law, investment companies are included in the list of credit institutions, and all legal norms aimed at credit institutions also apply to them. Therefore, investment funds (companies) strictly follow not only the provisions of the laws of KAGG, but also the provisions of the Law "On Credit Institutions". Therefore, the activities of both investment companies are also monitored by the Federal authorities that control credit institutions. Another distinctive feature of German investment funds is their depository structure. They, in turn, are tasked with securing securities and controlling companies that manage funds. This, in turn, is related to the protection of investors' rights. As mentioned above, the fund (company) receives funds from investors and provides them with a certificate of ownership. Investors' money can be used to issue securities, real estate or business development.

Objects relating to private assets may be the private property of an investment company or shareholders in proportion to the terms of the contract. But in any case, the private assets are kept separate from the private assets of the investment company. The activities of the management of the investment company are mainly alternated by two documents, namely, the company's charter and the terms of the contract with the fund. That is why the laws of KAGG are demanding of their activities. The terms of the agreement must be complied with and amended on the basis of bank supervision. The bank's permit can be issued only within the framework of the law, which stipulates the terms of the contract and amendments to them, and full protection of the rights of investors.

Such strict requirements to the terms of the contract are the main criterion for the decision to be made by investors when buying an investment share (stake). Permission to carry out various operations by an investment company is issued subject to the following conditions:

- The charter and founding capital of the company is $5 \mathrm{mln}$. not less than the euro and will be aimed at protecting investors. Because investment companies are guarantors of the funds raised, they are liable to investors for the damage caused to them;

- managers of investment companies have the necessary qualifications;

- There must be at least 2 managers for the company. This principle, in turn, ensures the strengthening of mutual control between the management of the company;

- prevented the misallocation of resources of the enterprise in accordance with the objectives of the investment fund, the types of activities specified in the agreement on the establishment of the company;

- The company's management and employees must focus their efforts on managing the fund and achieving efficiency.

Based on foreign experience in our country, we can form the following system for the organization and development of investment funds (Figure 1). 


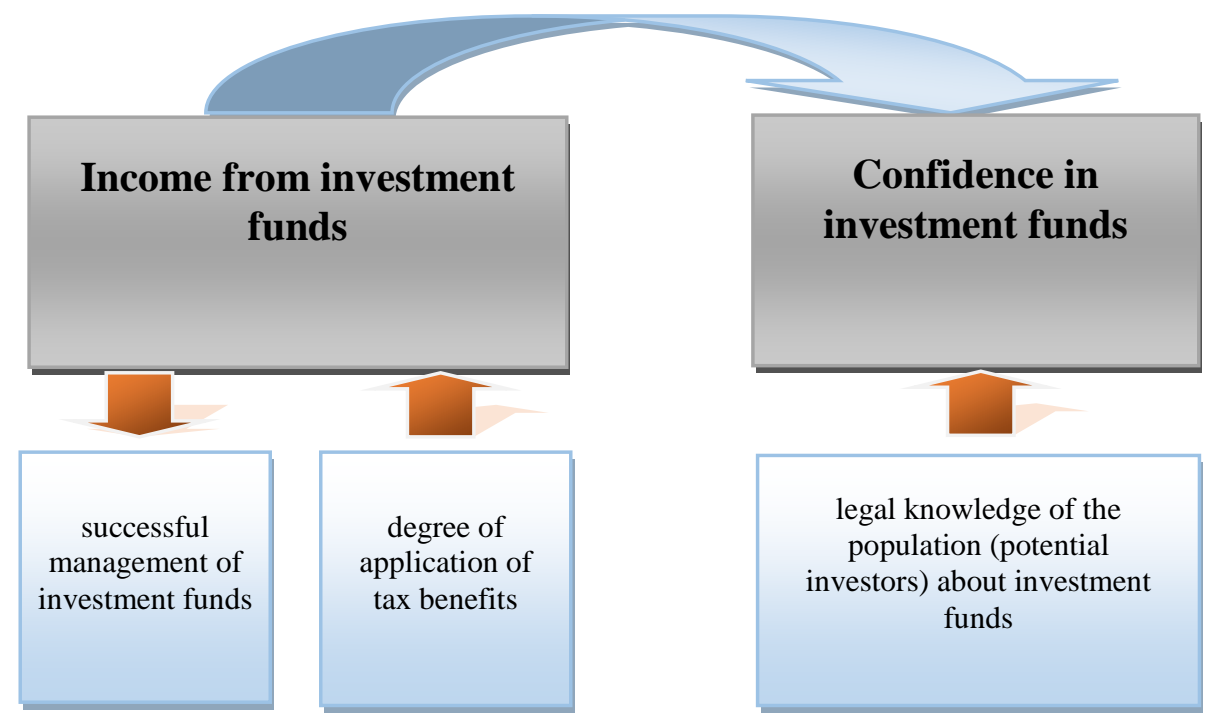

Figure 1. System of organization and development of investment funds in Uzbekistan

In accordance with the current legislation, the investment fund is required to have the appropriate funds to solve its tasks in the development prospects, to use the funds effectively and to find ways to increase it. Therefore, it is important to study the finance of investment funds through the analysis of the dynamics of its income, expenses and net profit.

According to the results of scientific research, the net assets of open and closed investment funds in the world have the main influence as an involuntary variable in the analysis of the process of formation of investment funds. The free variables are the net asset value of equity investment funds, the net asset value of investment funds whose assets are bonds, the net asset value of investment funds whose assets are denominated in currencies, and the net asset value of investment funds whose assets are mixed.

Given these arbitrary and arbitrary variables, we express them in the form of the following simple mathematical formula.

$\mathrm{TNAF}=\mathrm{F}(\mathrm{MF}, \mathrm{BF}, \mathrm{MF}, \mathrm{EF})(1)$

Here, TNAF (Total net asset close-end funds) is the net asset value of open and closed investment funds;

MF (Money funds) - the value of net assets of investment funds whose assets are in foreign currency;

BF (Bond Funds) - the net asset value of investment funds whose assets are in bonds;

MF (Mixed funds) - the value of net assets of investment funds, the assets of which include shares, bonds and currency;

$\mathrm{EF}$ (Equity funds) is the net asset value of an investment fund whose assets consist of shares. 
According to the Law of the Republic of Uzbekistan "On Investment and Share Funds", the investment fund of a joint-stock company is a legal entity that issues shares in order to attract investors' funds and invest them in investment assets.

In our opinion, investment funds play an important role in the effective placement of idle funds in production for the sustainable development of the economy of our country. This suggests that, in addition to regulating them directly, more attention should be paid to regulating them through market mechanisms. Also, the issue of licensing their activities as professional participants in the securities market remains one of the most pressing issues today. At the same time, some of the problems associated with the development of investment funds in our country can be identified as follows:

- small number of investment funds compared to other countries;

- Existence of aggravated requirements for supervisory boards of investment funds and trust managers of investment assets;

- low number of shares and net assets of investment funds of the country;

- Incomplete coverage of investment funds.

Currently, the lack of competitiveness of investment funds in the stock market, the inadequate functioning of the free market mechanism among joint-stock companies that own their shares, hinders the development of investment funds. Therefore, in the process of economic reforms in the country, we consider it necessary to take into account the following in the effective management of assets of investment funds operating in the country:

- the interests of the trustee in the effective management of investment funds' assets should be aligned with the laws of the market, ie the result achieved should depend on the results obtained as an incentive;

- the remuneration allocated to the trust manager should be used to encourage an increase in the value of net assets, ie it should be set in a stratified manner, taking into account changes in the value of net assets relative to the base year;

- Since the trustee has received an award for his service in previous years in the management of the fund's assets, he will be able to develop new business plans in the future, and so on.

\section{LIST OF REFERENCES}

1. Address of the President of the Republic of Uzbekistan Shavkat Mirziyoyev to the Oliy Majlis. December 22, 2017

2. Sharp U., Alexander G., Beyli Dj. Investments: Per. s angl. - M .: INFRA-M, 1999. - XII, $1025 \mathrm{p}$.

3. Shtolte P. Investment funds: Per. s.nem.-M. Finstatinform: interekspert, 1996.-168 p.

4. Abramov A. E, Akshentseva K. S, Chernova M.I, Loginova D.A, D.V. Novikov, Radygin A.D, Sivay Yu. V. Under obshch. ed. A.D.Radygina. Economics of investment funds. Monograph - M. : Izdatelskiy dom «Delo» RANXiGS, 2015. 
5. Pod red. A. D. Radygina. Institutional investors in the world. Features of activity and development policy. V 2 kn. Kn / 1 .. M .: Izdatelskiy dom «Delo» RANXiGS, 2014.

6. Sh.Sh. Shoha'zamiy «Methodological bases and priorities of strategic market development of tsennyx paper in Uzbekistan». Abstract T; 2011

7. Saidov R.B. The state of securities issuance in the financial sector of the country. Scientific journal "International Finance and Accounting". №4, August, 2020

8. Sultanov M.A. Opportunities to use foreign experience in creating mutual funds in commercial banks of Uzbekistan. Scientific journal "International Finance and Accounting". №4-5, August-October, 2018.

9. Abrorov Sirojiddin. The importance of sukuk in the development of the economy: as an example of its impact on the income of the Malaysian population. Journal of Critical Reviews. Vol 7, Issue 2, 2020. 